\title{
IDENTIFIKASI DAN DETERMINASI MDMA DALAM SAMPEL URINE DENGAN METODE KROMATOGRAFI LAPIS TIPIS
}

\author{
Desak Putu Ayu Suariyani ${ }^{1}$, Wiwin Mey Tjiang ${ }^{1}$, Putu Agus Andika Prayoga ${ }^{1}$, \\ Ni Made Widi Astuti ${ }^{1}$ \\ ${ }^{1}$ Program Studi Farmasi, Universitas Udayana, Bali, Indonesia \\ Email : putusuariyani@gmail.com
}

\begin{abstract}
ABSTRAK
MDMA (3,4-metilenedioksimet amfetamin) merupakan senyawa semisintetik turunan dari amfetamin tipe stimulan (ATS) yang bekerja dengan cara memicu pelepasan serotonin. MDMA sering disalahgunakan akibat efeknya yang dapat memicu euforia khususnya ditingkat remaja, zat ini sangat berbahaya karana dapat menyebabkan kematian pada pengonsumsi. Analisis MDMA untuk tujuan klinis maupun legal memerlukan suatu metode yang relatif cepat sehingga dipilih metode TLC dibandingkan yang lainnya. Uji identifikasi dilakukan dengan 3 sistem kromatografi yaitu metanol: amonia TA (100:1,5 v/v), metanol: butanol TAF (60:40 v/v), dan Toluena: aseton: etanol: amonia TAEA (45: 45: 7: $3 \mathrm{v} / \mathrm{v} / \mathrm{v} / \mathrm{v})$. Uji determinasi dilakukan dengan system TAEA dan digunakan MDMA sebagai standar. Hasil uji identifikasi menunjukkan benar dalam sampel terkandung MDMA melalui pendekatan Hrfc dan spektrum. Hasil determinasi menunjukka dalam sampel urin diperoleh masing-masing 134,53 $\mu \mathrm{g} / \mathrm{ml}$ dan 112,037 $\mu \mathrm{g} / \mathrm{ml}$.
\end{abstract}

Kata kunci: MDMA, Identifikasi, Determinasi, Kromatografi Lapis Tipis

\begin{abstract}
MDMA (3,4-methylenedioximet amphetamine) is a semisynthetic compound derived from amphetamine type stimulant (ATS) that works by triggering the release of serotonin. MDMA is often misused due to its effects that can trigger euphoria, especially at the adolescent level, this substance is very dangerous because it can cause death to consumers. MDMA analysis for clinical and legal purposes requires a method that is relatively rapid so that the TLC method is chosen over the others. Identification test were carried out with 3 chromatographic systems namely methanol: ammonia TA (100: $1.5 \mathrm{v} / \mathrm{v})$, methanol: butanol TAF (60:40 v / v), and Toluene: acetone: ethanol: ammonia TAEA (45: 45: 7: $3 \mathrm{v} / \mathrm{v} / \mathrm{v} / \mathrm{v}$ ). The determination test is carried out with the TAEA system and used MDMA as a standard. Identification test results showed that the samples contained MDMA through the Hrfc and spectrum approaches. The results of determination showed in the urine sample obtained $134.53 \mu \mathrm{g} / \mathrm{ml}$ and $112.037 \mu \mathrm{g} / \mathrm{ml}$ respectively.
\end{abstract}

Keywords: MDMA, Identification, Determination, Thin Layer Chromatography

\section{PENDAHULUAN}

MDMA (3,4-metilenedioksimet amfetamin) atau yang secara umum dikenal sebagai ekstasi merupakan senyawa semisintetik turunan dari amfetamin tipe stimulan (ATS) [1]. Tidak seperti golongan amfetamin lain contonhya amfetamin dan metamfetamin yang melepaskan dopamin dari terminal saraf, MDMA adalah stimulan kuat dengan memicu pelepasan serotonin [2]. Efek kognitif positif MDMA dalam klinis yang terkontrol mencakup peningkatan suasana hati dan kesejahteraan, kebahagiaan, relaksasi (fisik dan mental), peningkatan sensitivitas emosional dan responsif, keterbukaan yang meningkat, ekstroversi dan kemampuan bersosialisasi, empati, perubahan kecil dalam persepsi dan anticemas yang luar biasa [3].

MDMA kerap disalahgunakan dengan bentuk pil ekstaksi yang 16

Desak Putu Ayu Suariyani, Wiwin Mey Tjiang, Putu Agus Andika Prayoga, Ni Made Widi Astuti Program Studi Farmasi, Universitas Udayana, Bali, Indonesia 
pemakaiannya bertujuan untuk memperoleh efek psikologis yang diinginkan. Konsumsi MDMA dianggap tidak berbahaya oleh beberapa remaja namun nyatanya zat ini sangat berbahaya, terutama efek berbahaya pada hati, ginjal dan otak [4]. ekstasi telah dilaporkan menyebabkan kehilangan kesadaran, kejang, hipertermia, takikardia, hipotensi, koagulasi intravaskular diseminata, dan insufisiensi ginjal akut, serta kematian [5]. Namun meski efek samping dari MDMA sangat banyak dan berbahaya, penyalahgunaan MDMA tetap mengalami peningkatan setiap tahunnya. Amfetamin tipe stimulan seperti MDMA di banyak negara dianggap sebagai obat ilegal. Analisis zat ini memiliki minat dari sudut pandang toksikologi, kedokteran pekerjaan, dan penegakan hokum [6]. Sehingga perlu perhatian khusus terhadap MDMA dalam pengembagan analisisnya baik di bidang klinis maupun forensik.

Tahapan yang diperlukan dalam analisis MDMA adalah metode skrining, identifikasi, dan determinasi. Hasil analisis sangat dipengaruhi oleh jenis sampel yang digunakan, metode preparasi sampel, dan metode pengujian. Sampel yang digunakan pada penelitian ini adalah sampel urin. Urin merupakan bahan biologis penting untuk analisis Ekstasi, karena sekitar $50 \%$ senyawa tidak berubah (MDMA) dan proporsi produk biotransformasi mereka yang relatif tinggi dapat ditemui pada sampel dalam bentuk bebas atau terkonjugasi [7]. Beberapa metode seperti kromatografi gas (GC), spektrometri massa GC (GCMS), kromatografi cair kinerja tinggi (HPLC), elektroforesis kapiler (CE) dan Spektroskopi IR telah digunakan. Metode-metode ini memakan waktu, terutama mengenai diagnosis, karena sering memerlukan lebih banyak metode analitik untuk menemukan obat amfetamin [8]. Thin Layer Chromatography (TLC) adalah metode sederhana, cepat, murah, dan relatif selektif serta sensitif untuk analisis obat dan racun. Penentuan kuantitatif obat dan racun secara simultan telah membuatnya menjadi metode yang cepat [5]. Oleh karena itu penelitian ini bertujuan untuk melakukan identifikasi dan determinasi MDMA dalam sampel urin menggunakan metode kromatografi lapis tipis.

\section{METODE PENELITIAN \\ Bahan dan Peralatan}

Sampel Urin, Ammonia, $\mathrm{HCl}$ 37\%, Metanol, Tolene, Aseton, Aquadest, Ninhidrin, Asam asetat.

Strip $\mathrm{pH}$, Strip test, pipet tetes, botol vial, gelas ukur, Visualizer dan Scanner (Camag), Sentrifugator, Vortex, Pipet Mikro, Silica Gel 60 GF254, Chamber, Oven.

\section{Metode \\ Uji Skrining menggunankan Metode Strip Test}

Strip test disiapkan pada suhu ruang dan dikeluarkan dari bungkusnya. Strip test dicelupkan ke dalam Sampel urin sejumlah satu sampel dengan arah panah menunjuk tegak lurus pada sampel.

17

Desak Putu Ayu Suariyani, Wiwin Mey Tjiang, Putu Agus Andika Prayoga, Ni Made Widi Astuti Program Studi Farmasi, Universitas Udayana, Bali, Indonesia 
Tinggi sampel yang tercelup tidak boleh melebihi batas tinggi maksimal pada strip Kemudian proses deteksi ditunggu selama \pm 4 6 menit. Strip lalu diletakkan dipermukaan datar yang bersih dan tidak menyerap. Hasil yang diperoleh dapat dibaca antara. 10-30 menit setelah pencelupan dalam sampel.

\section{Ekstraksi Sampel Urin LLE}

$1 \mathrm{ml}$ sampel urine dipipet ke dalam tabung sentrifugasi lalu ditambahkan $1 \mathrm{ml} \mathrm{NaOH} 1 \mathrm{M}, 2,5$ $\mathrm{ml}$ akuades, dan $10 \mathrm{ml}$ kloroform: etil asetat: etanol (3:1:1 v/v/v). Divortex selama 10 menit disentrifugasi selama 5 menit dengan kecepatan rendah. Fase organik disaring dengan natrium sulfat dan filter di cuci dengan $2 \mathrm{ml}$ kloroform: etil asetat: etanol (3:1:1 v/v/v). Fase organik dipindahkan ke beaker yang telah berisi $25 \mu 110 \%$ $\mathrm{HCl}$ dalam methanol, kemudian diuapkan hingga kering

\section{SPE}

Catridge SPE di prekondisikan dengan $2 \mathrm{ml}$ methanol dan $2 \mathrm{ml}$ akuades. $1 \mathrm{ml}$ urin dilarutkan dengan $2 \mathrm{ml}$ buffer fosfat $\mathrm{pH} 6$, kecepatan penuangan sampel 1 tetes per detik. Dicuci dengan $2 \mathrm{ml} \mathrm{HCl}$ $0,1 \mathrm{M}$ dan $2 \mathrm{ml}$ methanol, dikeringkan menggunakan vakum selama 2 menit. Dielusi dengan $2 \mathrm{ml}$ $5 \% \mathrm{NH}_{4} \mathrm{OH}$ dalam $\mathrm{MeOH}$, eluat diuapkan.

\section{Uji Konfirmasi dengan TLC}

Fraksi fase organik dilarutkan dengan $50 \mu \mathrm{L}$ pelarut metanol.
Disiapkan 3 Plat KLT silica gel GF254 larutan sampel, larutan blanko (metanol) ditotolkan $20 \mu \mathrm{L}$, standar ditotolkan sebanyak $1 \mu \mathrm{L}$. Ketiga plat dielusi dengan fase gerak berbeda yaitu sistem TA metanol:ammonia (100:1,5 v/v), sistem TAF metanol:N-butanol $(60: 40 \mathrm{v} / \mathrm{v})$ dan sistem TAEA toluena:aseton:etanol:amonia (45:45 $: 7: 3 \mathrm{v} / \mathrm{v} / \mathrm{v} / \mathrm{v})$. Plat yang sudah kering disemprotkan dengan pereaksi ninhidrin. Plat yang telah disemprotkan menggunakan ninhidrin dimasukkan ke oven. Diamati perubahan warna yang terjadi. Kemudian dilakukan perbandingan spektrum dan penentuan hRfc untuk menentukan korelasi pada sampel dengan standar

\section{Uji Determinasi dengan TLC- Densitometri}

Fraksi fase organik dilarutkan dengan $100 \mu \mathrm{L}$ pelarut methanol. Disiapkan Plat KLT silica gel GF254. Ditotolkan larutan standar MDMA konsentrasi $500 \quad \mathrm{ng} / \mu \mathrm{l}$ sebanyak 2,3,4,8,10 $\mu \mathrm{L}$, fase organik hasil LLE (liquid-liquid extraction) sebanyak $10 \mu \mathrm{L}$. Dielusi dengan sistem fase gerak TAEA toluena:aseton:etanol:amonia (45:45 :7:3 v/v/v/v). Plat discan pada panjang gelombang $210 \mathrm{~nm}$

\section{HASIL dan PEMBAHASAN \\ Uji Skrining}

Uji skrining merupakan suatu pemeriksaan awal pada obat pada golongan yang besar atau metabolitnya dengan hasil presumptif positif atau negative. Sebelum dilakukan uji skrining 18

Desak Putu Ayu Suariyani, Wiwin Mey Tjiang, Putu Agus Andika Prayoga, Ni Made Widi Astuti Program Studi Farmasi, Universitas Udayana, Bali, Indonesia 
dilakukan pengecekan organoleptis urin. Hasil organoleptis warna urin kuning, dengan bau khas urine sedangkan $\mathrm{pH}$ urin yaitu 5 . Berdasarkan hasil yang diperoleh dengan menggunakan strip test, pada sampel urin positif mengandung psikotropika golongan amfetamin.

\section{Uji Konfirmasi}

Uji konfirmasi pada penelitian ini menggunakan metode Kromatografi Lapis Tipis yang mengacu pada TIAFT (The International Asosiation of Forensic Toxicologists) dan penelitian yang dilakukan oleh [9].

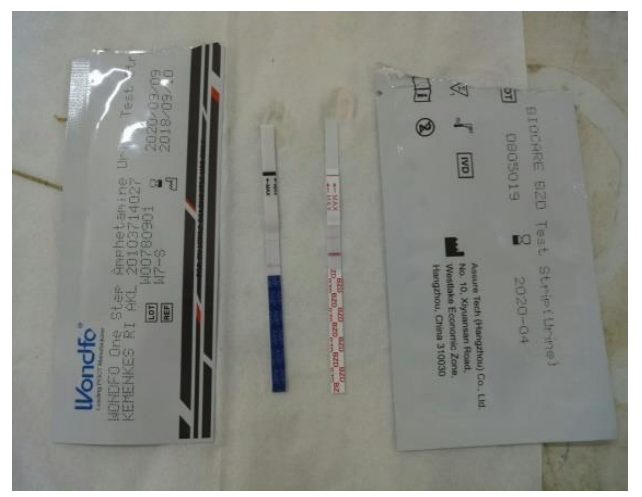

Gambar 1. Uji Skrining dengan Strip Test
Praktikum ini menggunakan tiga sistem yang terdiri atas sistem TA, TAF, dan TAEA sesuai dengan persyaratan minimal menggunakan dua sistem dalam uji konfirmasi yang tercantum dalam [10]. Pendekatan yang digunakan yaitu pendekatan hRfc dan overlay spektrum untuk menentukan senyawa yang terkandung dalam sampel. Keuntungan hRfc dibandingkan dengan harga hRf adalah nilai hRfc lebih konsisten dengan variasi faktor-faktor lingkungannya, sehingga dapat digunakan sebagai data yang lebih akurat dari senyawa yang dianalisis [11]. Sebagai pembanding ditotolkan baku pembanding seperti MDMA, morfin, dan kodein untuk menjadi acuan hrfc. Sementara itu senyawa yang dicurigai terkandung dalam sampel adalah MDMA atau amfetamin melihat pada SOC yang diamati.

Tabel 1. Nilai hRfc, error window dan keterimaan dari uji konfirmasi system TA, TAF dan TAEA

\begin{tabular}{ccccccc}
\hline \multirow{2}{*}{ Sistem } & \multicolumn{2}{c}{ TA } & \multicolumn{2}{c}{ TAF } & \multicolumn{2}{c}{ TAEA } \\
\cline { 2 - 6 } & LLE & SPE & LLE & SPE & LLE & SPE \\
\hline Hasil hRfc & 62,7 & 33,84 & 22,5 & 22,5 & 32,11 & 32,96 \\
Error Window & & 9 & & 9 & & \\
Keterimaan & $34-52$ dan 15-33 & 34-52 dan tidak ada & & \\
& & & & data MDMA & & \\
\hline
\end{tabular}

19

Desak Putu Ayu Suariyani, Wiwin Mey Tjiang, Putu Agus Andika Prayoga, Ni Made Widi Astuti Program Studi Farmasi, Universitas Udayana, Bali, Indonesia 
Hasi hRfc sistem TA diperkirakan pada sampel hasil SPE mendekati kedua hRfc dari senyawa yang diduga namun belum termasuk dalam rentang keterterimaan. Sementara itu sampel hasil LLE memiliki nilai hRfc yang sangat jauh dari senyawa yang diduga berada dalam sampel. Hal ini disebabkan karena tidak ada standar pembanding yang memiliki Rf lebih besar dari spot yang diduga senyawa golongan amfetamin. Hasil yang diperoleh dikuatkan dengan melakukan overlay spektrum

dengan spektrum library camag. Berdasarkan overlay spektrum diperoleh jika spektrum hasil LLE menunjukkan korelasi tertinggi untuk golongan amfetamin adalah etil MDMA dengan nilai korelasi 0,82434 dan untuk sampel hasil SPE adalah TMA dengan korelasi 0,77341 . Perbedaan hasil ini dapat terjadi akibat sampel yang diberikan perlakuan yang berbeda termasuk jenis pelarut yang ditambahkan untuk mengekstrasi analit dari mastrik urine akan berpengaruh terhadap hasil analisis.

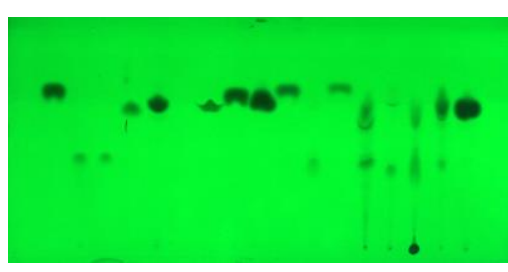

(a)

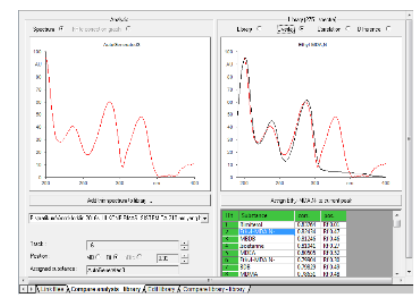

(b)

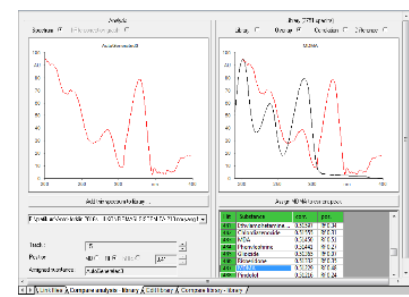

(c)

Gambar 2. Hasil dari sistem TA berupa spot (a), korelasi spektrum LLE dengan etil MDMA (b) dan kolerasi spektrum SPE dengan TMA

Hasil hRfc yang diperoleh pada sistem TAF tidak menunjukkan golongan amfetamin. Namun hasil overlay spektrum dengan spektrum library camag pada sampel LLE menunjukkan korelasi tertinggi untuk golongan amfetamin adalah etil MMDA dengan nilai korelasi 0,95982 dan untuk sampel hasil SPE adalah MMDA dengan korelasi 0,96016. Hal ini menunjukkan jika benar bahwa spot tersebut memiliki senyawa golongan amfetamin yaitu diperkirakan MMDA.

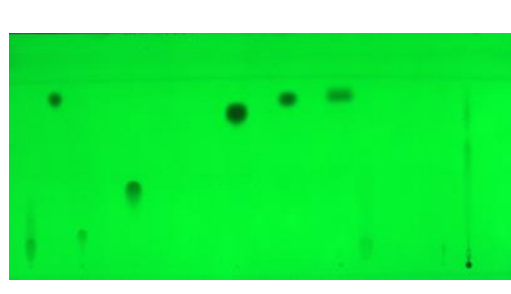

(a)

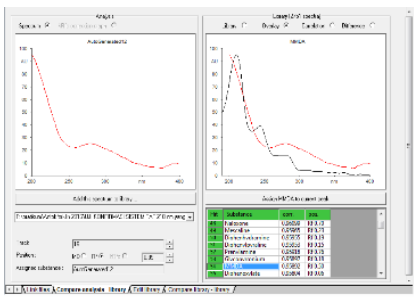

(b)

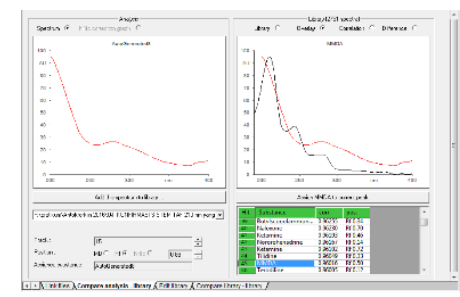

(c)

Gambar 3. Hasil dari sistem TAF berupa spot (a), korelasi spektrum LLE dengan etil MMDA (b) dan kolerasi spektrum SPE dengan MMDA

Sistem TAEA belum resmi tercantum dalam TIAFT sehingga 20

Desak Putu Ayu Suariyani, Wiwin Mey Tjiang, Putu Agus Andika Prayoga, Ni Made Widi Astuti belum didapatkan nilai error window serta keterterimaannya. 
Maka dari itu dilakukan overlay dengan spektrum standar MDMA yang juga ditotolkan diperoleh jika sampel hasil LLE dan SPE memiliki bentuk spektrum yang sama. Hasil overlay spektrum yang diperoleh pada sampel LLE menunjukkan korelasi tertinggi untuk golongan amfetamin yaitu etil MDA dan MDMA dengan nilai korelasi 0,99143 dan 0,98978 serta untuk sampel hasil SPE adalah MDMA dengan korelasi 0,99671. Oleh karena itu melihat pada SOC (scene of crime), nilai hrfc, dan overlay spektrum maka dapat dinyatakan jika golongan amfetamin yang terkandung dalam sampel urin tersebut adalah MDMA. Pada uji

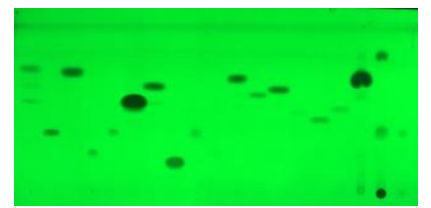

(a)

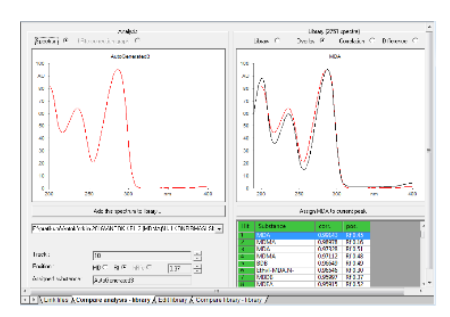

(b) konfirmasi diperoleh hasil berbeda antara sampel LLE dan SPE dapat terjadi karena beberapa pengaruh seperti $\mathrm{pH}$ urin, suhu, dan waktu penyimpanan. Selain itu mekanisme kerja untuk ekstraksi dengan LLE dan SPE juga berbeda. Sehingga analit yang dihasilkan memiliki perbedaan yang signifikan. Meski pada sampel LLE korelasi spektrum lebih besar pada MDA dibandingkan MDMA tetap dapat disimpulkan sebagai MDMA yang terkandung karena MDA merupakan metabolit dari MDMA yang dapat ditemukan pada sampel urin [12].

Gambar 4. Hasil dari sistem TAEA berupa spot (a), korelasi spektrum LLE dengan MDA (b) dan kolerasi spektrum SPE dengan MDMA

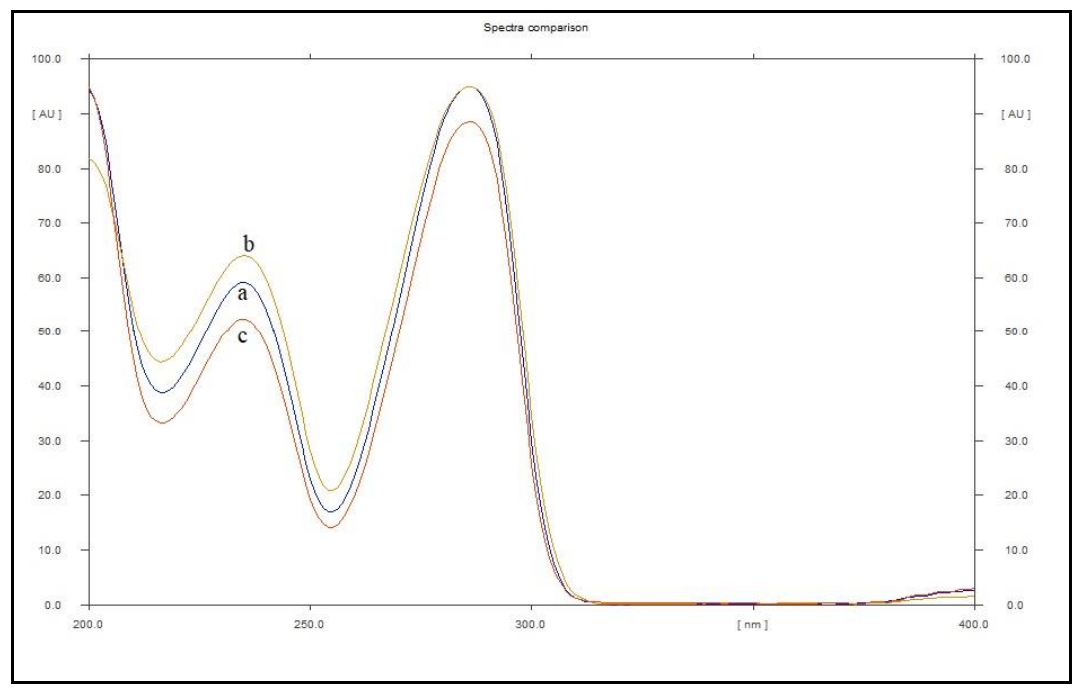

Gambar 5. Overlay spektrum standar MDMA (a) dengan spot pada track sampel hasil LLE (b) dan SPE (c) pada rf yang sama.

21

Desak Putu Ayu Suariyani, Wiwin Mey Tjiang, Putu Agus Andika Prayoga, Ni Made Widi Astuti Program Studi Farmasi, Universitas Udayana, Bali, Indonesia 
Uji determinasi dilakukan dengan sistem fase gerak TAEA yang dipilih berdasarkan hasil uji konfirmasi yang terbaik. Tahapan determinasi menggunakan 5 larutan seri dengan konsentrasi yang berbeda. Pemilihan konsentrasi larutan seri didasarkan atas perbandingan AUC dari standar sampel LLE yang ditotolkan pada uji konfirmasi. Selanjutnya dari 5 konsentrasi seri yang digunakan dipilih 3 konsentrasi yang menghasilkan nilai $\mathrm{r}^{2}$ mendekati 1 , yaitu larutan seri 1, 2, dan 5 dengan masing-masing konsentrasi 1000 ng, $2000 \mathrm{ng}$, dan $5000 \mathrm{ng}$. Nilai $\mathrm{r}^{2}$ yang diperoleh adalah 1 . Kemudian dapat dihitung LOD dan LOQ (batas deteksi dan batas kuantifikasi) dari hasil yang masing-masing sebesar 18,63 ng dan 62,12 ng.

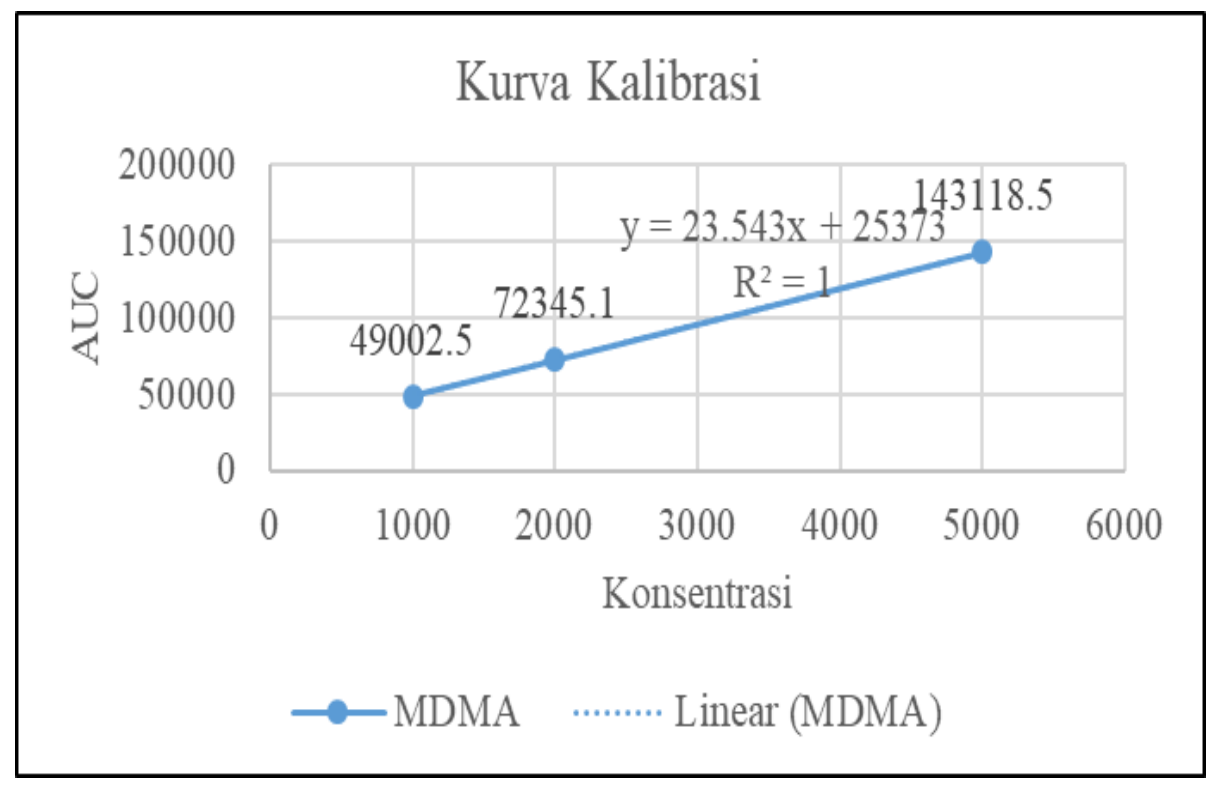

Gambar 6. Kurva kalibrasi dari 3 konsentrasi larutan seri

Setelah itu, dilakukan penetapan kadar MDMA dalam sampel LLE. MDMA dalam sampel LLE replikasi pertama yang diperoleh adalah $1452 \mathrm{ng}, 1226,9$ ng, dan 1356,6 ng dengan konsentrasi dalam volume totolan $10 \mu \mathrm{L}$ adalah $145,2 \mu \mathrm{g} / \mathrm{mL}, 122,7$ $\mu \mathrm{g} / \mathrm{mL}, \quad$ dan $135,7 \quad \mu \mathrm{g} / \mathrm{mL}$.
Konsentrasi dalam sampel LLE replikasi kedua yang diperoleh adalah $1198,8 \mathrm{ng}, 1134,9 \mathrm{ng}$, dan 1027,4 ng dengan konsentrasi dalam volume totolan $10 \mu \mathrm{L}$ adalah untuk replikasi pertama sebesar 119,88 $\mu \mathrm{g} / \mathrm{mL}$, replikasi kedua sebesar $113,49 \mu \mathrm{g} / \mathrm{mL}$, dan replikasi ketiga sebesar $102,74 \mu \mathrm{g} / \mathrm{mL}$. 
Tabel 2. Nilai AUC dari uji determinasi

\begin{tabular}{ccccc}
\hline Senyawa & $\begin{array}{c}\text { Konsentrasi } \\
(\mathrm{ng} / \mu \mathrm{L})\end{array}$ & Totolan & $\begin{array}{c}\text { Konsentrasi } \\
\text { totolan (ng/spot) }\end{array}$ & AUC \\
\hline Seri 1 & 500 & $2 \mu \mathrm{L}$ & 1000 & 49002,5 \\
Seri 2 & 500 & $3 \mu \mathrm{L}$ & 1500 & 69570,7 \\
Seri 3 & 500 & $4 \mu \mathrm{L}$ & 2000 & 72345,1 \\
Seri 4 & 500 & $8 \mu \mathrm{L}$ & 4000 & 107211,5 \\
Seri 5 & 500 & $10 \mu \mathrm{L}$ & 5000 & 143118,5 \\
Sampel LLE O 1 & - & $10 \mu \mathrm{L}$ & - & 59557,5 \\
Sampel LLE O 1 & - & $10 \mu \mathrm{L}$ & - & 54257 \\
Sampel LLE O1 & - & $10 \mu \mathrm{L}$ & - & 57312,1 \\
Sampel LLE O 2 & - & $10 \mu \mathrm{L}$ & - & 53596,9 \\
Sampel LLE O 2 & - & $10 \mu \mathrm{L}$ & - & 52090,8 \\
Sampel LLE O 2 & - & $10 \mu \mathrm{L}$ & - & 49561,3 \\
\hline
\end{tabular}

Berdasarkan [10], apabila seseorang mengkonsumsi MDMA setara dengan $0,4-0,8 \mathrm{mg} / \mathrm{L}$ berarti seseorang telah mengkonsumsi MDMA dalam jumlah yang sangat banyak dan dapat menyebabkan toksisitas akut. Hal ini diperkuat kembali melalui penelitian dari [13] yang menyebutkan bahwa konsentrasi MDMA yang ditemukan dalam urine seorang pria berumur 29 tahun yang meninggal akibat MDMA sebesar 118,8 mg/L. Hasil yang diperoleh menunjukkan bahwa sampel urine yang diteliti mengandung MDMA dengan dosis letal. Ekstasi/MDMA merupakan psikotropika golongan I yang merupakan jenis psikotropika yang hanya dapat digunakan untuk tujuan ilmu pengetahuan dan tidak digunakan dalam terapi, serta mempunyai potensi amat kuat mengakibatkan sindroma ketergantungan [14].

\section{KESIMPULAN}

Serangkaian uji skrining, konfirmasi dan determinasi dilakukan untuk mengidentifikasi psikotropika pada suatu sampel. Sampel urin yang diperiksa positif mengandung psikotropika dan diduga mengandung senyawa MDMA.

\section{DAFTAR PUSTAKA}

[1] Phonchaia, A., B. Janchaweeb, S. Prutipanlaib, dan S. Thainchaiwattanac. Solid Phase Extraction for GC-FID Determination of 3,4Methylenedioxymethampheta mine (MDMA), 3,4Methylenedioxyamphetamine (MDA) and Methamphetamine (MA) in Human Urine. Journal of 23

Desak Putu Ayu Suariyani, Wiwin Mey Tjiang, Putu Agus Andika Prayoga, Ni Made Widi Astuti Program Studi Farmasi, Universitas Udayana, Bali, Indonesia 
Analytical Chemistry. 2012; 67 (2): 122-130.

[2] Flomenbaum NE, Howland MA, Goldfrank LR, Lewin NA, Hoffman RS, Nelson LS. Goldfrank's toxicologic emergencies. New York: McGraw-Hill; 2006.

[3] Thal, S. B., dan M. J. J. Lommen. Current Perspective on MDMAAssisted Psychotherapy for Posttraumatic Stress Disorder. Journal of Contemporary Psychotherapy. 2018; 48:99108.

[4] Duffau, S. R., L. A. Delgado, S. Jofre. 2015. High Performance Thin Layer Chromatography method for analysis of 3,4methylenedioxymethampheta mine in seized tablets. Journal of Pharmacy \& Pharmacognosy Research. 2015; 3 (6): 162-170.

[5] Boushehri, S. V. S., M. Tamimi, dan A. Kebriaeezadeh. Quantitative determination of 3,4methylenedioxymethamphe tamine by thin-layer chromatography in ecstasy illicit pills in Tehran. Toxicology Mechanisms and Methods. 2009; 19 (9): 565569.

[6] Gimeno P, Besacier F, Chaudron-Thozet H. Optimization of extraction parameters for the chemical profiling of 3,4methylenedioxymethampheta mine (MDMA) tablets.
Forensic Sci Int. 2003; 132(3): 182-194.

[7] Lasmar, C. dan E. M. A. Leite. Determination of 3,4Methylenedioxymethampheta mine (MDMA) and 3,4Methylenedioxyamphetamine (MDA) in Urine by High Performance Liquid Chromatography Marcelo. Analytical Letters. 2009; 42: 2556-2566.

[8] Lalali, A., A. Hatamie, T. Saferpour, A. Khajeamiri, T. Safa dan F. Buazar. Impact of Pharmaceutical Impurities in Ecstasy Tablets: Gas Chromatography-Mass Spectrometry Study. Iranian Journal of Pharmaceutical Research. 2016; 15 (1): 221229

[9] Wirasuta, I.M.A.G., Primaningrum, I.A.S., Astuti, K.W. Uji Konfirmasi Penetapan Kadar Morfin dengan KLTSpektrofotodensitometri. Indonesian Joirnal of Legal and Forensic Sciences. 2014; 4: 5-7.

[10] Moffat C, Osselton MD, Widdop B. Clarke's Analysis of Drugs and Poisons. 4th ed. London: Pharmaceutical Press; 2011.

[11] Zeeuw DRA, Jan PF, Fritz D, Gunther M, Harald S, and Jaap W. DFG (Deutsche Forschungsgemeinschaft) and TIAFT (The International Association of Forensic Toxicologist), Thin-Layer Chromatographic Rf Values of Toxicologically Relevant 
Substances on Standardized Systems, Second, Revised and Enlarged Edition, Report XVII of the DFG Commission for Clinical-Toxicological Analysis and Special Issue of the TIAFT Bulletin. Weinheim: $\quad \mathrm{VCH}$ Verlagsgesellschaft; 1992.

[12] Valtier S, Phelix CF, Cody JT. Analysis of MDMA and its metabolites in urine and plasma following a neurotoxic dose of MDMA. J Anal Toxicol. 2007; 31 (3):138-43.

[13] Crifasi J and Long C. Traffic Fatality Related to the Use of Methylenedioxymethampheta mine. J Forensic Sci. 1996; 41 (6): 1082-1084.

[14] UU RI. Undang-Undang Republik Indonesia Nomor 5 Tahun 1997 tentang Psikotropika. Jakarta: Direktorat Jenderal Pelayanan Kefarmasian dan Alat Kesehatan; 1997. 